\title{
AN INTRODUCTION \\ TO INSTITUTIONAL COORDINATION \\ AS AN ALTERNATE MODEL FOR NEO-INSTITUTIONAL ECONOMIC ANALYSIS
}

\author{
RUBÉN MÉNDEZ REÁTEGUI*
}

Fecha de recepción: 20 de marzo de 2013.

Fecha de aceptación: 25 de junio de 2013.

Resumen: En este trabajo, mediante la formulación de un modelo conceptual, el autor vincula los conceptos de empresarialidad funcional e instituciones apuntando a presentar una exploración del concepto de coordinación institucional o interacción institucional positiva como elemento esencial para el análisis económico. El objetivo es introducir la hipótesis de que la coordinación institucional entre las instituciones formales e informales es el elemento clave a dilucidar con miras a completar la elaboración de una teoría de las instituciones más consistente. Esta dilucidación se expresa a través de las siguientes contribuciones: a) La interacción institucional negativa es un proceso en el que los desplazamientos y sobre posiciones entre reglas formales e informales no pueden ser dejadas fuera del modelo; b) Una discusión de la relevancia y características de la tasa marginal de sustitución técnica en el ámbito de lo institucional —relevante sobre todo al momento de estimar la mejor combinación posible de las instituciones formales e informales-; c) Una exploración de los determinantes de la elasticidad institucional —que se corresponderían con la facilidad con la que una «institución formal» puede ser sustituida por una «institución informal» y viceversa-; d) El uso del enfoque de Neurociencias y del sistema de recompensa del cerebro, los cuales son presentados como una herramienta para mejorar el análisis de la coordinación institucional.

* Rubén Méndez R. is a researcher in the Department of Economics at Macquarie University in Sydney in Australia and visiting scholar at Complutense University of Madrid and Salamanca University in Spain

Procesos de Mercado: Revista Europea de Economía Política Vol. X, n.․ㄹ 2, Otoño 2013, pp. 151 a 197 
Palabras clave: Empresarialidad Funcional, Reglas Formales e Informales, Coordinación Institucional, Interacción Institucional Positiva, Elasticidad Institucional, Fuentes del Derecho.

\section{Clasificación JEL: B52, K00, Z13.}

Abstract: In this paper, through the formulation of an alternate conceptual model, the author links the concepts of functional entrepreneurship and institutions, understood as a set of categories - formal and informal rulesshowing a complex, dynamic and interactive character. Furthermore, the aim of this paper is to introduce an exploration of the concept of institutional coordination or positive institutional interaction as an essential element for neo institutional economics analysis. This aim proposes the hypothesis that institutional coordination or positive interaction among formal and informal institutions is the real key element for a theoretically consistent and comprehensive analysis, evaluation and testing of institutions. Moreover, the paper is attached to the «meta» concept of society, represented as a process of dynamic collaboration among individuals. This assumption seeks to suggest an improved theoretical standard through the insertion of concepts taken from classical legal theory such as «desuetude» and "contra legem custom». This theoretical standard leads the author to introduce a set of contributions to the contemporary heterodox economics literature: a. Negative institutional interaction is a process where overlapping and displacement between formal and informal rules cannot be leaved outside the model; $b$. A discussion in terms of institutional marginal rate of technical substitution becomes important for deciding the best possible combination of formal and informal institutions; c. An exploration of the determinants for institutional elasticity, as the author assumes, that determinants of institutional elasticity mainly correspond to the ease with which a «formal institution» can be replaced by an «informal institution» and vice versa; $d$. The use of the brain reward system and the Neuroscience approach introduced as a tool to improve the analysis of institutional coordination. Together the significance of these contributions brings a secondary hypothesis: traditional neo institutional analysis is weak, in the sense that, it avoids dealing with the real role and relevancy of informal institutions shouldering the prevalence of the formal institutional framework to reach institutional predictability and a sustainable social order. Therefore, the author claims that the traditional analysis is mistaken as it indirectly supports a separation and confrontation between contributions emerging from the legal abstract theory of the sources of law (Ghersi, 2007) and economic analysis. 
Key words: Functional Entrepreneurship, Formal and Informal Rules, Institutional Coordination, Positive Institutional Interaction, Institutional Elasticity, Sources of Law.

JEL Classification: B52, K00, Z13.

\section{INTRODUCTION}

All further measurement or empirical analysis requires a conceptual or theoretical model since measurement or empirical research without theory is vacuous. In this regard, the conceptual framework must elaborate the substantive problems of concern, specify the particular hypotheses that require investigation and provide a set of operational definitions of the variables that are regarded as central to the analysis.

Therefore, the main purpose of this paper is to provide a conceptual and theoretical overview of the "state of the art» of the phenomenon named institutional coordination or positive institutional interaction in correlation with an alternate understanding of the concepts of functional entrepreneurship ${ }^{1}$ and institutions as have been proposed by Israel Kirzner (1978) and Douglass North (1990) respectively.

With regards to this, the specific objectives are: 1) To introduce a successful conceptual model for further qualitative and quantitative studies; 2) To introduce and describe the concept of institutional coordination; 3) To highlight the particular problems that arise when analysing some theoretical characteristics of those societies in correlation with the level of institutional coordination

\footnotetext{
${ }^{1}$ Entrepreneurship is an essential concept for the development of the theoretical framework discussed in this paper. The entrepreneurship function is defined here as the human ability to discover new entrepreneurial opportunities. According to Kirzner (1973), the entrepreneurship function refers to every individual, not just another factor of production or a simple microeconomic concept, and is primarily related to the level of uncertainty in the market. The same author suggests (but did not introduce any further exploration) that improving dynamism through informal institutions can reduce uncertainty.
} 
(strength or weakness); 4) To briefly show the advantages of an alternate approach as a harmonizing instrument seeking to improve the adoption of perspective (such as Institutional Quality) as it has been traditionally understood by contemporary heterodoxmarket-oriented economics.

As the aim of this paper is to develop the notion of institutional coordination, from an alternate perspective, it is important to understand that contributions from legal, sociological and nonstandard economic theory were considered complementary. Interdisciplinary research focused on: a) the relevance of institutions, b) individuals interacting as complex and dynamic groups, and c) economic agents expressing the essence of the entrepreneurship function. These require a unified methodology as understood by classical economists like Smith or one of the fathers of the marginal utility approach, Carl Menger (1976 [1871]). This is not a matter of «academic labels» or «fancy proposals,» on the contrary; this is essential to build a better explanation of how the interaction between functional entrepreneurship and institutions can affect a country's economic performance and growth.

Therefore, in order to introduce the concept of institutional coordination or positive institutional interaction, an explanation has been built about the relevancy of an economic theory of rules for a successful economic assessment. In this sense, we depart from the hypothesis that institutional coordination or positive interaction between and among formal and informal institutions is the real key element for a theoretically consistent and comprehensive analysis, evaluation and testing of institutions (rules of the game). There is also a secondary hypothesis: traditional neo institutional analysis is weak, in the sense that, it avoids dealing with the real role and relevancy of informal institutions shouldering the prevalence of the formal institutional framework to reach institutional predictability and a sustainable social order. In addition, we also claim that the traditional analysis is mistaken as it indirectly supports a separation and confrontation between contributions emerging from the legal abstract theory of the sources of law (Ghersi, 2007) and economic analysis. Therefore, this paper introduces a conceptual model where this separation is stopped in order to effectively integrate economic and legal analysis of 
institutions. Moreover, institutions have been presented as economic goods, which can be evaluated not only through the use of classic concepts such as marginal value and cost but also in terms of elasticity. Consequently, the paper introduces a preliminary proposal where the determinants of institutional elasticity have been classified and roughly described.

Therefore, the first chapter will explore the theoretical significance of coordination among institutions and how the interaction of subjective preferences and production factors is mediated through several layers, that is, through legal, social, cultural and political institutions or rules; the second chapter will discuss the relation among institutions and society. In this chapter a society is presented as an example of spontaneous order, thus, as a highly complex structure not consciously designed by anyone and comprised of human interactions carried out according to certain rules, habits, or standards of conduct. The third chapter introduces an explanation of how the lack of positive institutional coordination or coordination problem emerges. The fourth chapter presents a discussion of the institutional marginal rate of technical substitution due to a consistent analysis of institutional coordination, which requires deciding the best possible combination between and among formal and informal institutions. The fifth chapter explores the determinants of institutional elasticity. It has been assumed that determinants of institutional elasticity mainly corresponds to the easiness that a «formal institution" can be replaced by an «informal institution» and vice versa. In addition, the sixth chapter explores how the brain reward system and institutional coordination are linked. We considered that contributions coming from the Neuroscience approach would become an essential tool to complete the conceptual model proposal and any further analytical and theoretical explorations. Finally, sets of conclusions are submitted. 


\section{II \\ THE RELEVANCE OF COORDINATION AMONG INSTITUTIONS}

One of the main effects of the leading neoclassical paradigm within economic theory after 1850 was the «rejection» of aspects not considered as pure economics such as pure subjective preferences and entrepreneurial judgements, functional entrepreneurship with and without access to capital, knowledge and information, rules (institutions) formation, discovery or production, etc.

This was a great contrast to the thinking of the classical economists like Smith, Malthus, and Ricardo, who had stressed the importance of the social, cultural and political analysis of economic phenomena on a particular basis. According to Boettke et al. (2010):

Classical economists saw the market as a process of competitive rivalry and dynamic entrepreneurial discovery. They placed importance on the economics of organizations and examined the political process with the same behavioural assumptions that they used to examine the market process. [Italics added]

However, interest in the interaction between the social-political environment and the economy (meaning a humanistic approach) remained attached to the heterodox tradition, specifically in later authors like Menger. According to Klein (2007):

Menger favoured an approach that was deductive, teleological, and, in a primary sense, humanistic. (...), he was primarily interested in explaining the real-world actions of real people, not in creating artificial, stylized representations of reality. [Italics added]

In this regard, the theoretical deep fissure that has survived into the economic mainstream years later allowed modern-marketoriented heterodox economics to reach increasing notoriety (Roux, 2006). For these economists, economics was the study of purposeful human choice, the relationship between means and ends 
guided by complex rules: institutional rules. ${ }^{2}$ Inspired by this perspective, in this paper we will consider that «economics has to be understood as an exchange or the science of social exchange. More precisely, we understand economics as an exchange of property rights developed and guided by a set of formal and informal rules (institutions) and carried out by the entrepreneur in an evolutionary social context.»

Furthermore, economic approaches such as the Neo Austrian and the New Institutional were able to show that the interaction of subjective preferences and production factors is mediated through several layers, that is, through legal, social, cultural and political institutions or rules. Consequently, the difference in levels of performance and economic development among countries was better understood with a coordinated institutional framework, which denotes divergent levels of productive (Baumol, 1990) and functional entrepreneurship (Foss et al., 2010).

A coordinated institutional framework in close connection with the exercise of functional entrepreneurship is essential to introduce an incentive scheme that results in economic outcomes that can be categorized as efficient (i.e., allowing social fabric to unfold in an atmosphere of low transaction costs) because it creates a structure to encourage economic growth. This also means

\footnotetext{
${ }^{2}$ Generally speaking, it can be stated that society is ruled by two kinds of institutions: Formal (statutes, etc.) and informal institutions (customs, etc.). The Government, represented by the legislative, executive and judicial powers, introduces formal institutions or rules. These institutions are static and arise from the monopolistic power of government. Informal institutions are dynamic, and their legitimacy and enforcement are based on the need for social acceptance. Even though there is a difference between formal and informal institutions, there is also a level of interdependence between these sorts of institutions. Formal institutions create a fundamental social order and coordination, which is important for the development of informal institutions, whereas informal institutions reflect the level of social acceptance or rejection of the society's formal institutions. This scenario has been described as the «competitive character» of formal and informal institutions where a society will no longer recognize poorly developed formal institutions, and will progressively substitute them with new informal institutions. Formal and informal institutions cannot be isolated. We believe that a comprehensive institutional analysis has to perceive the existing chains between both groups of rules. In this paper, the complex chains created by formal and informal institutions will be referred as «institutional network».
} 
that the institutional framework and entrepreneurship have shaped property rights and markets have provided an environment where competition (process of rivalry) can exist and flourish. Without the existence of entitlements or rights showing vigorous property rights, individuals could not invest in human or physical capital, develop or adopt new technologies or implement new ideas. When the institutional framework suffers from a serious lack of coordination it does not allow markets to flourish. This is attributable to its distortion by the ruling government, and therefore, the resources tend to be allocated incorrectly (diseconomies).

These diseconomies can negatively impact societies seeking to promote innovation through the market process and individuals looking to achieve «prosperity» in a context of voluntary cooperation and non-aggression. Consequently, an institutional framework that cannot prevent social failures by, for example, stopping perverse behaviour on economic agents such as politicians, bureaucrats or unproductive (mercantilist) entrepreneurs (Ghersi, 2009) will affect efficient growth, better income creation and redistribution through the market process. Therefore, a framework of coordinated institutions matters because it helps to solve a key economic problem for agents: coordination of their entrepreneurial projects and the development of specific productive activities based on efficient economic calculation.

Beyond that, it has raised an emerging consensus that the institutional framework plays a key role in shaping the growth (North, 1990) and developing nations (Acemoglu, 2005). In addition, it is important to consider the role that the institutional framework has in promoting economic change and sustainability, in other words, towards a statement that explains the differences in economic growth and development among countries with different social environments.

Although many economists agree on the objectives and the relevant role of the institutional framework - in general- the concept of institutions differs in economic literature. Economists have not introduced a definition that can be considered as generally accepted, because of the lack of a unified economic theory of institutions themselves. As a result, the definition of institutions is a currently open debate. According to Hodgson (2006): 
The use of the term institution has become widespread in the social sciences in recent years, reflecting the growth in institutional economics and the use of the institution concept in several other disciplines, including philosophy, sociology, politics, and geography. [Italics added]

Following this, a brief literature review will show that multiple definitions exist, though many of them are extremely narrow, general or vague (San Emeterio, 2006). It is assumed that this topic is important because institutions are not simple legal statutes in first and last social order but are evolutionary mechanisms with a grade of homogeneity and temporal transcendence (as they were known in the Republican Rome). Therefore, it can be stated that institutions vary in shape, size, importance and role, and are not stress-free to transplant or transfer (almost impossible in the case of informal institutions) from one country or region to another, differing significantly not simply among developing countries, but also in conjunction with those of developed nations. Furthermore, even in a formal sense they are problematic to define because they include rules or legal mandates (written laws) and dynamic rules that govern social interaction in a society (evolutionary rules as customs and social practices).

From a neo institutional point of view according to Gagliardi (2008), in an effort to synthesize and extend their understanding, institutions can be classified into three categories. The first category considers institutions as the rules of the game. As it has been described by North (1990):

Institutions are the rules of the game in society or, more formally, are the humanly devised constraints that shape human interaction. In consequence they structure incentives in human exchange, whether political, social, or economic. [Italics added]

The second category, presented by Nelson's previous research (1994), describes institutions as the players participating in the game. This idea is later shown and quotes by Aoki (2007):

Nelson identifies institutions with prominent organizations such as «industry associations, technical societies, universities, courts, government agencies, legislatures», etc. [Italics added] 
In addition, Gagliardi (2008) states that this definition considers the role of those who have to enforce rules and assure that individuals comply with them. As this author has explained, this is important because:

(...) along with the rules in force, this definition considers also the role played by those who have to apply the rules and ensure they are respected by others, as well as the organizations. In this context, examples of institutions are universities, courts, industry associations, government agencies etc.

The third category considers institutions as the result of the self-fulfilling balance of a game. As observed by neo-institutional scholars (Agandoña, 1991), this apparently broad definition consists of two interrelated elements: a. perception of the players, and $b$. organizations that modify the game. In the same vein, and following previous research from Schotter (1981), Gagliardi (2008), has stated:

(...) this definition considers institutions as the self-enforcing equilibrium outcome of the game (...). More precisely, institutions are made up of two interrelated elements: the beliefs individuals form on others' behaviour and the organizations, which can alter the rules of the game.

In regards to this last category, Aoki (2007) states that an institution represents a "self-sustaining system of shared beliefs». ${ }^{3}$ Aoki's theoretical approach balances North's view, since it barely focuses on the value of institutions or rules, but also the way that the game needs to be played or coordinated (second category). Therefore, it is necessary to consider:

a. The degree of interaction among institutions (formal and informal) and its relevant sub types that can be rescued from Ro-

\footnotetext{
${ }^{3}$ Gagliardi (2008) also refers that this third category has been extensively explored from a games theory approach: «This last view has been further elaborated by using the evolutionary game approach (see Aoki, 1995; Bowles, 2001; Sugden, 1986 and 1989; Young, 1998, among others) and the repeated game approach (Calvert, 1995; Greif, 1989, 1994a, 1997a and 1998a; Greif et al., 1994; Milgrom et al., 1990).»
} 
man law and Civil law scholars (Ghersi, 2007). The purpose of referencing institutional sub types is to save the general classification of sources of law used in the civil law tradition (continental European law). In that sense, we believe that more than one category of both formal and informal rules exist. Nevertheless, this fact has been extensively studied by legal theory without necessarily and explicitly establishing a connection, even with contributions from modern heterodox economics.

b. To understand how the players (individuals exercising functional - productive or unproductive- entrepreneurship) assume their key role.

However, to cope with a proliferation of interpretations, it is desirable to maintain a consistent view. In this regard, North's contributions (1991) should be understood as a starting point. North (2005) describes institutions as «humanly devised constraints» which are due «to structure the political, economic and social interaction.» These human limitations can be divided into formal constraints (constitutions, laws, regulations) and informal constraints (involving taboos, customs, codes of conduct, social uses), in other words, manufactured restrictions that —as it was shown by Barry (1997)-, shape spontaneous human interaction. This conceptualization provides a valuable road-map indicating how humans interact with each other as individuals or social groups (inside a complex political, social or economic process). That is, institutional studies have to be closely linked to ideas awaiting further development such as institutional competition, institutional opportunity cost and a mixed theory (law and economics) of institutional evolution and change (Mendez, 2011). These are important because even describing this phenomenon on a different basis the mainline institutional analysis did not assumes the existence of institutional competition. According to Meisel et al., (2007):

The system of regulation that continues to dominate the social sphere remains based on personal ties and relationships, observance of unwritten and strict norms (submission to authority, to tradition, etc.). (...) Confidence (in the relation to authority, the circulation of information, and the observance of rules) is produced and shared on an idiosyncratic basis, in other words, in the light of the intrinsic cha- 
racteristics of individuals or their membership to a group (...). [Italics added]

\section{The essence of Institutions:}

\section{a revision of customs from a legal approach}

From a theoretical legal approach, customs that are the main mechanism to represent an informal institution are considered a source of law of formal nature. In Roman law they had been stated in two basic forms: a. Don't harm anyone, b. Give to each his own. Currently, in Civil Law family customs are described as constant repetition of habits. In addition, when customs represent or concur with legal standard features is called «legal or juridical customs». Those customs enforce behaviours and have become obligatory. Customs are legal for their perseverance, repetition and security. Following this approach a law has to state whether or not a social practice or custom is allowed. In this order of ideas, some Latin American and European Constitutions have empowered customs, recognizing them through the following Civil Law Constitutional principle: «no one is obliged to what the law does not require, nor deprived of what is not prohibited». Moreover, when a law is based on and arises principally from custom it is called customary law. Then, custom may have the authority to replace statutory when a «desuetudo case» arises, if statutory law does not provide a legal alternative or if Constitutions or other top statutes agree to empowered customs. This idea has been followed mainly by the Civil Law system. Consequently, in the Civil Law system, customs are understood as a formal source of law. This legal tradition classifies customs into three different types according to their relation with statutory law:

- Customs Secundum Legem (by law): The law recognizes customs or customs agree with a statute.

- Customs Praeter Legem (outside the law).- They create a customary rule regarding a situation not covered by the law.

- Customs Contra Legem (against the law or «desuetude»).- They are generated against the provisions of the law (statute), and therefore try to repeal it. 
Conversely, for the Anglo-Saxon Common law, a system born and based on the case law rather than in statutory law, it is important to understand that customs have a psychological approach. This psychological approach is the belief that customs (social behaviour) establish a right and obligation to be carried out by individuals, communities or societies. Therefore, customs refer to an ancient rule for a particular space (regions or communities). In addition, customs are considered as the valid rule of law for an extended space (country). This idea has its origin in the AngloSaxon period. In this period, local customs formed most of the legal framework ruling a variety of matters such as family rights, inheritance, contracts, ownership and personal violence. Legal historians have discovered that Norman conquerors approved the legitimacy of those rules based on ancient customs (later known as customary law) and found a way to adapt the customary system of regulation to their feudal structure of government and juridical organization. Subsequently, after historical and social transformations, customs (formally called «customs of the realm») finally became «common law». In this particular scenario, a custom outside of common law was considered valid if and only if:

1. Customs had been practiced peaceably and continuously from time immemorial (as long as living testimony can recall).

2. Customs were confined to a specific locality and, therefore, could be defined as rule of law governing a specific community or region.

3. Customs represented a mechanism showing reasonable, certain, and obligatory substance

This juridical framework is useful for developing a theory based on informal institutions. Since a discussion of institutional coordination or positive institutional interaction shows the previously described interaction between customs types, it can be fully translated from an economic perspective and it keeps flexible cultural characteristics - in a framework ruled by an evolutionary perspective- where informal rules or customs retain their validity. 


\section{Functional Entrepreneurship in terms of PPF}

The Production Possibility Frontier (PPF) is a useful tool to show how the entrepreneur, when performing two essential functions for economic growth, is also helping to strengthen institutional coordination. These functions are: a. Productive entrepreneurship (Baumol, 1990) empowers current profit opportunities and eliminates inefficiencies. Therefore, an economy will move from an inefficient point (A) towards an efficient one (B) and will reduce the risk of lacking social cohesion by strengthening harmonious or positive interaction among institutions. b. Consequently, by introducing innovation, defined as the discovery of a new technology or new production process using existing resources more efficiently, productive entrepreneurship contributes to the shift of the PPF to the right: achieving an increase in real output due to increases in productivity.

According to Klein (2008), another key link between productive entrepreneurship, institutional coordination (positive institutional interaction) and economic growth is that productive entre-

GRAPH 1

EFFECTS OF ENTREPRENEURSHIP ON THE PPF

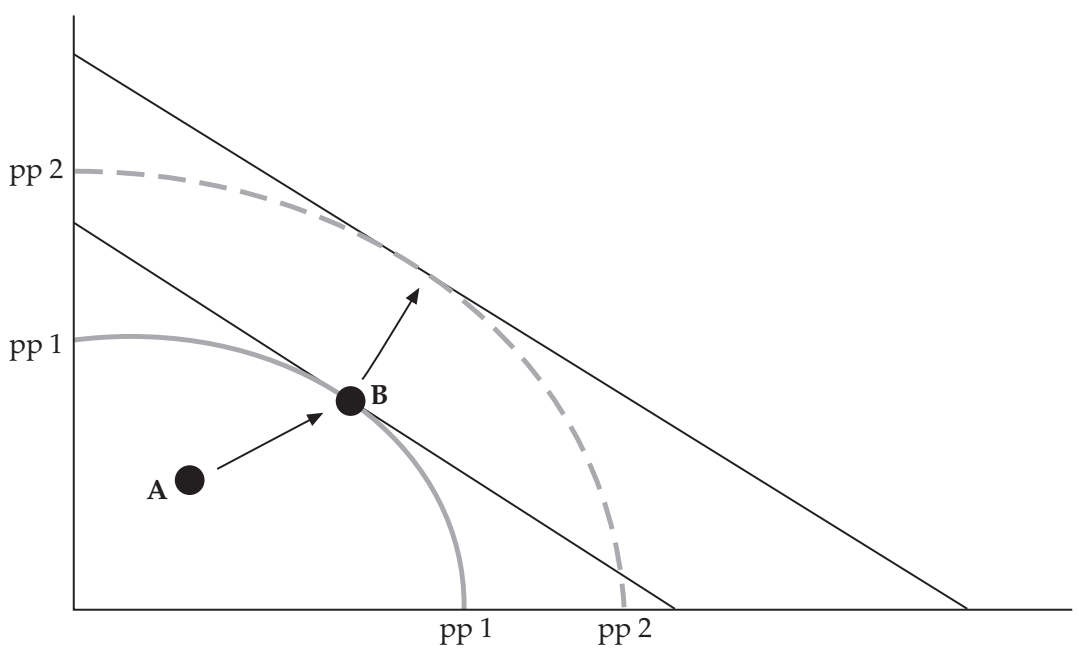

Source: Boettke y Coyne (2003), p. 74. 
preneurship creates new market niches that require innovation (forming a virtuous circle or «win-win» process). Therefore, this pool creates opportunities and better uses of resources where institutions can be considered as essential vehicles that positively organize and facilitate economic development. In addition, productive entrepreneurship would then enable Developing economies to successfully carry out further well-coordinated institutional changes (avoiding the risk of a weak and irresponsible institutional transplant). Following a more traditional approach, these changes can be classified and understood as essential for keeping high standards of growth and economic development. Developed economies, however, will successfully keep high economic rates and standard of innovation, and therefore, continued economic and institutional dynamism (Acemoglu et al., 2012).

III

SOCIETY, INSTITUTIONS AND INSTITUTIONAL COORDINATION

A society can be defined as a group of interactions among individuals. This means an evolutionary process and dynamic collective structure which is: a. spontaneous and thus not consciously designed by anyone; $b$. highly complex, since it comprises billions of people with an infinite range of goals, tastes, valuations, and practical knowledge; and c. composed of human interactions which basically refer to exchange (often expressed through monetary prices) and are always carried out according to certain rules, habits, or standards of conduct.

All such human interactions are motivated by the force of entrepreneurship, which continually creates, discovers, and transmits information, as it adjusts and coordinates the contradictory plans of the different individuals through competition and enables them to coexist in an increasingly rich and complex environment. In addition, these kinds of interactions are regulated through institutions. Then, the legitimacy and the dominance of these institutions will depend on the level of individual and collective acceptance and their capacity to adapt to social change. 
Furthermore, it is also essential to establish strong formal and informal institutions to maintain an organized and competitive society. This approach has been the mainline of neo institutional economics. According to Chang (2011):

Since the late 1990s, the view that poor-quality institutions are the root cause of economic problems in developing countries has become widespread. In accordance, the IMF and the World Bank started to impose many "governance-related conditionalities", which required that the borrowing country adopts «better» institutions that improve "governance».

Furthermore, strong institutions can impact positively on economic growth and performance, but they also impact on social cohesion, dynamism and proactive individual interaction (Alonso et al., 2008). Societies with a harmonious interaction between formal and informal institutions can be categorized as structured societies. Specifically, structured societies reflect a social context where:

- Individuals can rapidly adapt themselves to their social context (dynamic efficiency),

- Societies show the interdependence between formal and informal rules that we have called institutional coordination or positive institutional interaction. It is understood as a complex human interaction involving interdependence and rejection after a certain level of institutional confrontation. The possibility of institutional rejection introduced the concept of social or tacit abrogation and derogation of formal rules (Ghersi, 2007).

Alternatively, when a society does not have a positive interdependence between formal and informal institutions, there emerges social stagnation or institutional weakening, which refers to an elevated lack of institutional coordination or negative institutional interaction. In this social context, individuals cannot adapt to social change and manifest negative social behaviour. We propose that the level of institutional weakening can be used as a social indicator to analyse and classify a society's social performance. 
Consequently, to measure welfare and induce efficiency in the analysis we need to incorporate several social scenarios, due to the divisions that occur in a civil society (García-Guadilla et al., 1997). Finding a way out of these «negative scenarios» is a challenge that can be undertaken through different "corporate forms» that express the prevalence of functional entrepreneurship. These different corporate forms cannot be regulated with a traditional bureaucratic approach. Instead, a strategic deregulatory reform becomes a priority, in the short term, to achieve institutional coordination. Similarly, we have stated (Mendez, 2011) in a previous publication that:

Unlike the traditional concept of deregulation, strategic deregulation does not exclusively involve the process of revision, adjustment, and removal of specific laws and regulations by government that affect the business environment. Strategic deregulation is based on the principle of strong property rights and the prevalence of the entrepreneurship function. In addition, strategic deregulation also deals with the positivistic legal paradigm that assumes a necessity for proactive formal rules (public policies) (Kelsen, 2001; Hart, 1980). At the other extreme, public policies from a strategic deregulation perspective focus on the lifting of legal and social barriers, which are negatively impacting the dynamic adjustment and performance of the institutional framework (North 1990). In addition, these barriers inhibit the capacity of individuals to adapt to social change.

On one hand, the concept of institutional coordination introduces the idea of a community of interest or economics as an exchange of property rights. In this context, social issues are not missing out the social fabric, but depend upon productive and functional entrepreneurship and an efficient social interaction (organized by institutional coordination). This can be measured through a basic index of access to welfare represented by legal stability or civic rationality. ${ }^{4}$ Hence, in a context with strong civic rationality, functional entrepreneurship will indirectly induce strong

4 This paper defines «legal stability» or «civic rationality» as causally efficient motivation for public-spirited action. 
political governance. In some way, -following Weber's approach (1964) - coordination problems that are affecting the social fabric are fixed by auto-generated institutions and other social mechanisms. ${ }^{5}$

On the other hand, institutions representing political governance are weak and their weaknesses open doors to forms of power where the crash among social groups (domination and social cost transferences) is permanently presented. Therefore, it leads to a scenario where political, economic and social stability is a derivative of the struggle among groups. Consequently, any scenario of social coordination is temporary in nature.

This conceptual model considers that individuals have a propensity to seek social coordination (dynamic equilibriums), which is compelled to share links and generate different degrees of social interaction. This process also requires an institutional framework where interaction between formal and informal rules is functional. All this can be framed within a cultural and social cohesion. If this process is added to the individual and group aspirations, it requires a degree of institutional stability, which is achieved to the extent that the functional entrepreneurship and the political and economic environment point to a non-destructive competition context.

Also, it is necessary to contemplate the capabilities of the social fabric presented as a dynamic combination of human resources permanently dedicated to cultural change and technological development. This is relevant to illustrate that without dynamic efficiency, limited (rational) political governance and the contribution of functional entrepreneurship, institutional coordination cannot be achieved and a lack of social cohesion will follow. Then, the so-called destructive entrepreneurship (Baumol, 1990) manifested through mercantilist activities becomes an «institutionalized activity.» Consequently, this situation affects individual and group aspirations (which in an opposite scenario have to be harmoniously and accessibly organized or materialized

\footnotetext{
5 According to Weber's «Theory of Domination» (1964), it is possible to place the State as the most involved organisation (for political and taxation purposes) in the consolidation of legal certainty and resource use in the law.
} 
by the «Volk») and inhibits informal institutional arrangements from becoming formal arrangements (understood as stable and predictable social instruments for organization and control). In this regard, it can be suggested that coordination among institutional arrangements cannot be represented as a supply or activity carried out only by formal government bodies. Even in a traditional political scheme, governments are considered responsible for organizing the dynamics within the social fabric. Following a similar approach, it can be stated that the formal supply of Rule of Law or «Rechtsstaat» (E.g. a constitutional network, treaty or code) cannot generate an «institutional framework» introducing a structured society. Therefore, the supply of formal institutional goods does not create its own demand and depends on additional «mixture» of social elements to reach the «market equilibrium» as it has been described by the modern heterodox economic theory.

IV

\section{INSTITUTIONS AND THE «COORDINATION PROBLEM»}

A correlation among a normative (Legal and Constitutional Theory ${ }^{6}$, Socio-Political and Economic analysis is required to understand the positive and negative interaction among formal and informal institutions. In particular, negative institutional interaction is a process where overlap and displacement between formal and informal rules cannot be left outside the model. This process is referred to as the coordination problem and it is fed by social disruption and characterised by leading societies from the structured to the unstructured category and vice versa (Mendez, 2011).

An important fact arises when considering this particular scenario of formal rules. In contrast to what happens with informal rules, a formal authority prescribes formal rules and their

\footnotetext{
${ }^{6}$ From a standard legal perspective a formal institution is a rule intended to manage human behaviour according to principles such public interest and the social contract conception.
} 
noncompliance might involve a formal penalty or administrative fine. Generally speaking a formal rule imposes duties and confers «official» rights. In addition, it differs from informal standards of conduct in the following ways:

- Its heteronomous character (imposed by the government or other formal authority).

- Its bilateral characteristics (there is an agent -individual - compelled to meet the rule's standard and another agent - authority- is enforcing them).

- Its coercible approach (rules are enforceable through sanctions and the use of formal power in case of breach).

- Its external character (compliance with the statute is the most important matter).

However, formal rules (ratio) are not completely different to informal rules (actio). Both kinds of rules have a prescriptive character. ${ }^{7}$ Therefore, formal and informal rules consist of a complex set immersed in an evolutionary process guided by the government and civil society. Conclusively, even if the collection of formal rules is often referred to as legislation and regulation, this peculiar characteristic does not deny the presence of a key coordination problem fed by social disruption looking to reach a state of dynamic efficiency (Huerta de Soto, 2009) as described above. $^{8}$

In addition, a discussion of the role of institutional coordination is characterised by the encouragement of institutions to «send a message» (contextualized by the mainstream of Economic Analysis of Law scholars as "price»). This price reflects a state of equilibrium in the institutional framework and the absence of a

7 Therefore, «normative principles» can be described as an additional category characterised by their broad «descriptive character».

8 Agreements or contracts without a formalized support can be described also as informal rules. A formal framework often exists behind this particular category. However, its uncommon dynamics do not obey ratio but are finally supported by actio. In addition, an agreement can be changed rapidly to satisfy the interest of agents involved. A formal institution lacks a dynamic character. This sometimes explains their peculiar construction and it is represented by its cost structure. 
«coordination problem» (as described previously). However, in the real world, individuals have to face the lack of institutional coordination and the impact of those institutions, which effectively guides human behaviour. Then, where coordination between formal and informal rules remains a problem, individuals cannot behave as price takers and the idealist presence of an institutional competitive market cannot be successfully supported.

TABLE 1

\section{INSTITUTIONAL COORDINATION EFFECTS}

\begin{tabular}{|c|c|}
\hline Institutional Coordination: YES & Institutional Coordination: $\mathrm{NO}$ \\
\hline $\begin{array}{l}\text { - If and only if, a «consistent» } \\
\text { interaction between institutional } \\
\text { types can be found. As a generic } \\
\text { requisite, this interaction refers to a } \\
\text { period of general institutional } \\
\text { stability (reached by structured } \\
\text { society in a context of institutional } \\
\text { strength). } \\
\text { - Effective coordination between } \\
\text { institutional types works with a } \\
\text { society in order to reach social } \\
\text { (government) and individual } \\
\text { objectives. } \\
\text { - Institutional Strength (description): } \\
\text { Price, value and cost leads to positive } \\
\text { and negative interaction. }\end{array}$ & $\begin{array}{l}\text { - Accelerated interaction between } \\
\text { institutional types as first step. } \\
\text { - Competition between institutional } \\
\text { states becomes a more notorious issue } \\
\text { and leads to an institutional process } \\
\text { where the overlap and displacement } \\
\text { of institutional types is clearly an } \\
\text { observable issue. } \\
\text { - This state of «strong discoordination» } \\
\text { between institutional types refers } \\
\text { first to transitional societies and then } \\
\text { to unstructured societies. It also } \\
\text { refers to a degree of institutional } \\
\text { weakness. } \\
\text { Institutional weakness: Signs of } \\
\text { non-competitive legal markets lead to } \\
\text { alternative regulatory mechanisms } \\
\text { (informal rules). Fragmented } \\
\text { normative framework. }\end{array}$ \\
\hline
\end{tabular}

In addition, it is important to consider that an informal institutional framework guiding human behaviour among individuals has been introduced by the Community and not by the State. The community is a social scenario characterized by strong longterm interaction among its members. This positive interaction is enhanced by elements like interpersonal trust and a common faith system (North, 1991). Also, the development of a process of longterm coordination between informal rules (informal institutions' network) has helped to establish voluntary and cooperative ties. 
This is important because, despite the paths introduced by the majority of neo institutional scholars, formal and informal institutions cannot be isolated. We believe that a comprehensive institutional analysis has to perceive the existing chains between both sets of rules. In this paper, the complex chains created by formal and informal institutions will be referred to as a «network».

These restrictions are not the result of the State's mechanisms of social control; nonetheless, they are the result of a complex self-regulatory process. This process is closely related to the kind of economic system leading the society. The particular and uncommon interaction in a social scenario governed by informal institutions is explained by customs and other alternate mechanisms of self-regulation. These mechanisms will grow naturally where the formal institutional framework cannot reduce transaction costs. Also, the relations between economic agents and governmental organizations are characterised by high transaction costs, so economic agents have a strong incentive to move to the informal institutional framework. From a static efficiency perspective this represents a negative collective choice because outside the «formal market» individuals have to face corruption and negative entrepreneurship as the cheapest option to move from a state of lower satisfaction to one of higher satisfaction. Consequently we disagree with those views that suggest that institutions have to be policed only or mainly by centralized authorities. Therefore, as Schotter (1981) writes, it is always necessary to assume that an institution:

(...) is a regularity in social behaviour that is agreed to by all members of society, specifies behaviour in recurrent situation and is either selfpoliced or policed by some external authority. [Italics added]

In addition, a low transaction cost environment is the perfect place for the development of the entrepreneurship function because social and economic incentives come from a context where individuals trust the informal set of rules. Therefore, the informal set of rules represents an efficient incentive mechanism and a low transaction cost scenario, where individuals show their alertness or creative capacity. This capacity allows them to efficiently 
improve the allocation of rights (resources) from agents unable to discover new entrepreneurial options to agents capable of advancing the current system of production (Ostrom, 1990). However, this approach is contested by mainstream economics (Alonso et al., 2008) which considers that no efficient economic displacement could be undertaken in a context where informal institutions are leading an unconventional mechanism for social integration and expansion as it has been shown by the following diagram.

\section{DIAGRAM 1}

INFORMAL INSTITUTIONS AND COMMUNITY ACTION

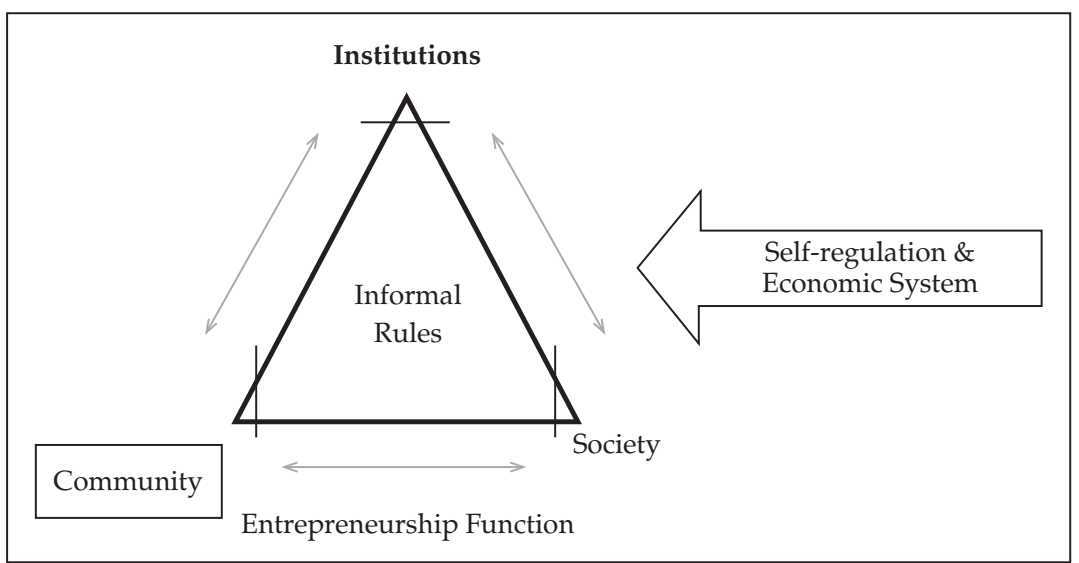

However, we argue that a successful analysis of the coordination problem cannot be mainly guided by a disputable empirical approach. Empirical studies focused on institutional analysis usually lack an extensive understanding of the meaning and development of rules by complimentary areas of knowledge such as Legal Theory, Sociology and Anthropology. As Alonso (2012) has outlined:

(...) these studies usually rest on a very limited scrutiny of historical experience. [Italics added]

In addition, according to Meisel et al. (2007): 
As populations and markets grow, as the economy becomes more complex and more open, as the opportunities for trade increase, the cost of observing rules under the previous mode increases with each new transaction. This is because the personal investment required by the predominant regulation system (confidence based on the quality of interpersonal ties) is extraordinarily time-consuming. [Italics added]

Following this approach, the formal institutional framework introduces a second theoretical scenario shown in diagram 2.

DIAGRAM 2

FORMAL INSTITUTIONS AND THE STATE

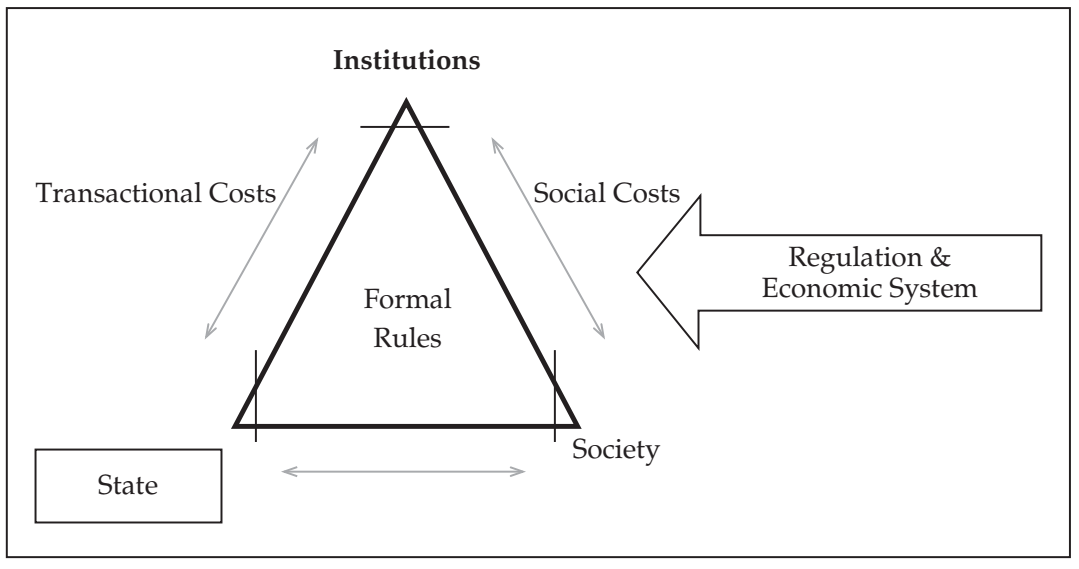

In this context, social and economic incentives are introduced by the State through public policies represented by formal mechanisms such as the national law (codes and statutes), and administrative, national, regional and local regulation, etc. Therefore, a set of formal rules is the cheapest system for society to move from a state of collective depression, social costs and institutional weakness to a better social scenario. Consequently, for some scholars such as Alonso and Garcimartin (2008), a formal institutional framework seems to be the most efficient mechanism to introduce social order, predictability and economic incentives for improving economic planning through public, private and combined initiatives. 
However, we disagree with this constrained approach. Following Stigler (1992) it can be stated:

(...) every durable social institution or practice is efficient, or it would not persist over time. New and experimental institutions or practices will rise to challenge the existing systems. Often the new challenges will prove to be inefficient or even counterproductive, but occasionally they will succeed in replacing the older system. Tested institutions and practices found wanting will not survive in a world of rational people. To believe the opposite is to assume that the goals are not desirable: who would defend a costly practice that produces nothing?.

In addition, we believe that empirical studies - even though recognised by the mainline and mainstream for their relevancy to illustrate a fact - have to take into consideration the historical experience of the institutional framework that they aim to analyse. This is necessary to strength their illustrative capabilities and avoid making statements such as follows:

In developing countries, the shift to the formalisation of regulation systems has not occurred (Meisel et al., 2007).

Such statements do not consider the "advances» introduced in developing countries (mainly belonging to the Civil law tradition) where the formalization of regulatory systems did not necessarily show a positive contribution strengthening institutional coordination and its relevant framework. Likewise, it is essential to contemplate theoretical (fundamental) differences existing between the Rule of Law (where a State shows separation of powers, where citizens are equal before the law and where these laws limit the political power) and Rule of Legality (where the law reflects and protects the political power rather than limits it). In developing countries the formalization of regulatory systems has driven their legal system to the second scenario.

Therefore, going back to our previous point, it is accurate to believe that when there is a lack of institutional coordination only the «cheapest» institutional framework or network will survive. A priori means that the formal institutional framework is not per se the most efficient social development. Even though in a scenario 
where regulation, codes, statutes and common law coming from governmental branches introduce a short, mid or long-term normative equilibrium, human action expressed by its entrepreneurial function and individuals" "temporary» preferences will occasionally move economic agents to the best institutional framework and network. It means that in the real world, politicians and other policy makers cannot block Smithian's selfish economic and social behaviour. Consequently, in order to understand how social and individuals preferences works (expressed through alternate modes of production), it is necessary to recognize the process of interaction between informal and formal rules. This is because in the real world economic agents have to face pure entrepreneurial and economic action. As stated before, this action must be understood as a process of social exchange, more precisely, as an exchange of property rights developed and guided by a set of interactive formal and informal rules (institutions) and carried out by the entrepreneur in an evolutionary social context.

DIAGRAM 3

SOCIAL, POLITICAL AND ECONOMIC ORGANIZATION THROUGH NORMATIVE INSTRUMENTS.

RULE OF LAW AND INSTITUTIONAL COORDINATION

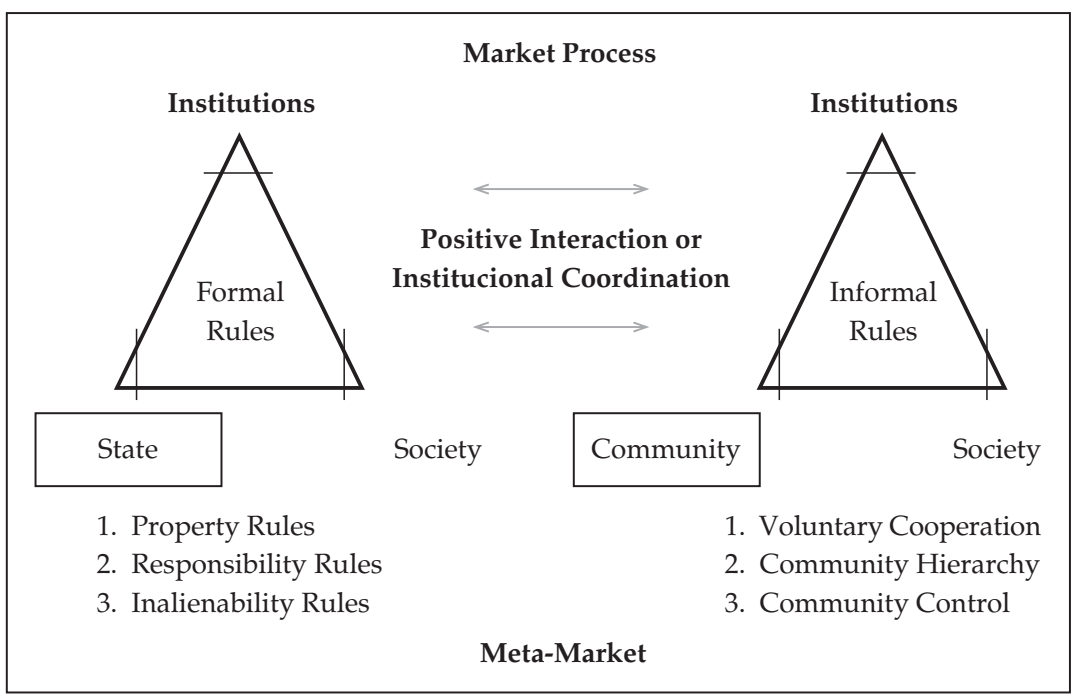


The next diagram illustrates this interaction or interdependence between formal and informal institutions, their enforcement mechanisms, and the collective agents involved:

DIAGRAM 4

INTERACTION OR INTERDEPENDENCE BETWEEN FORMAL AND INFORMAL INSTITUTIONS

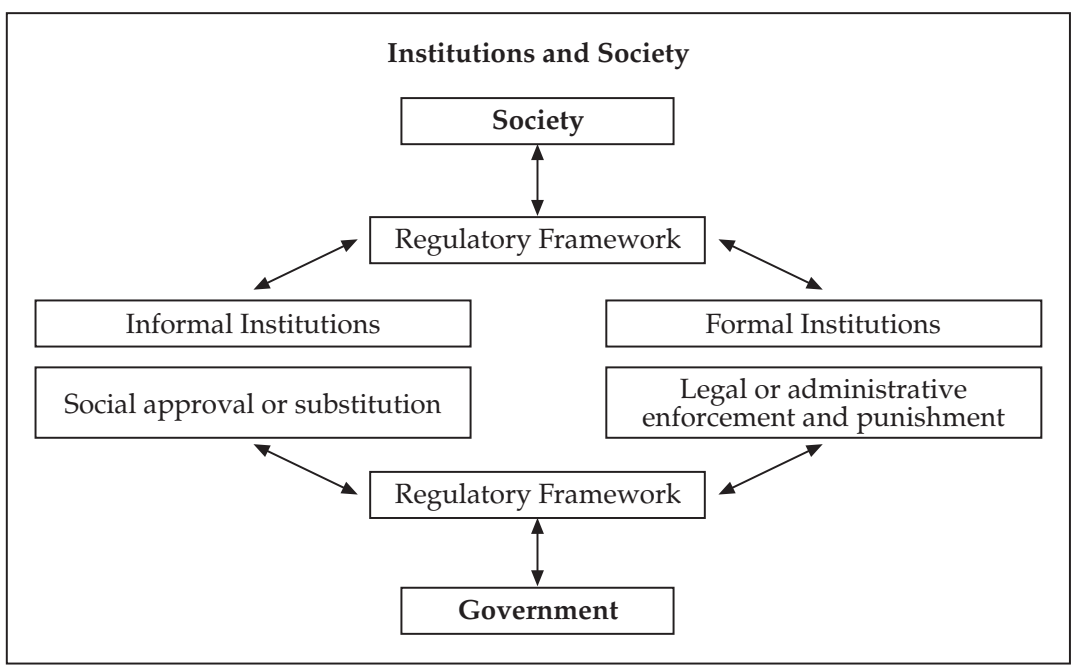

We believe that this priori is the correct approach and the level of institutional consumption of individuals will change according to the state of the social process. Individuals living in an accelerated social process will require the most efficient institutional mechanisms to adapt themselves to new social circumstances. This is a subjective valuation difficult to predict by a central planner because of a lack of information and practical knowledge.

This also illustrates the relevance of the coordination problem between formal and informal institutions. Then this problem will persist based on individual perception of cost and benefits. However, this coordination problem can be collectively influenced. Thus, we argued that the coordination problem occurs in a context of a high degree of institutional weakness. This turns out to be a relevant fact if we analyse a particular scenario where formal 
institutions or rules are unable to reflect the precise benefit for individuals (measured in terms of marginal value - Vmg-) when there is a complex set of rules introduced by the government (measured in terms of marginal cost - Cmg-). In this complex scenario, a society has to face a social contradiction: Individuals perceive a high Vmg when they do not use the official institutional market. This market is a government monopoly with clear restrictions that allow it to rapidly adapt itself to individuals' expectations and needs. At this point, the Cmg of producing rules (legislation and regulation) for the government becomes an unorthodox way to understand the coordination and the monopoly issue involved: The government will reach a point where increasing the production of formal rules will not produce a «profit». That is, the production of formal rules has to face a context where the total cost of the formal institutional system increases at a higher rate than the profits, and where the marginal cost of the institutional system for the government will also begin to rise. ${ }^{9}$

This interaction between formal and informal institutions occurs within a context of the market process. From a microeconomic perspective, this institutional interaction is manifested through the exercise of the entrepreneurship function. Moreover, the organization of the market process demonstrates the necessity for rules that cooperate based on the opportunity cost of their provision and consumption. Also, this institutional interaction affects the structural arrangement of the institutional network. In the formal institutions framework these structural arrangements relate to the rules of property, liability and inalienability (Calabresi and Melamed, 1972). Meanwhile, the informal institutions framework relates to voluntary cooperation, hierarchy and communal control. The main feature of this network is to establish «trade-offs» or «compromise solutions» where the

9 The marginal cost compliance with the formal institutional framework is defined as the change in their total cost, with one-unit increase in their quantity of rules produced by the government or the cost of producing an additional formal rule. Mathematically this change can be represented as the partial derivative of the total cost divided by the quantity of formal rules introduced in the formal institutional framework. 
absence of governmental coercive power is evidenced. Therefore, these compromise solutions or trade-offs are a response to a scenario where formal institutions, by themselves, cannot efficiently reduce transaction costs. Finally, the process of interaction among institutional types occurs within a wider orbit called a meta-market. Therefore, this orbit implies the organization of social, political and economic guidelines through «normative instruments or principles» defined as an additional category characterised by a broad descriptive character.

\section{$\mathrm{V}$ \\ INSTITUTIONAL COORDINATION AND MARGINAL RATE OF TECHNICAL SUBSTITUTION}

A consistent analysis of the paradigm of institutional coordination requires deciding the best possible combination among formal and informal institutions. These combinations can be arbitrarily represented with a PPF analysis as it can be a useful tool to show, for example, how a society can produce 10 units of $Y$ (formal institutions) and discover 5 units of $X$ (informal institutions); or does not discover more than 10 units of $X$ and allocate most of its resources in order to produce 5 units of Y. However, this assumption needs to take into account a random variable: entrepreneurs can positively or negatively (unproductively) manipulate available institutional resources. This conduct can be described as the positive or negative entrepreneurial power. It represents the unique behaviour of individuals, who are permanently looking to satisfy their own interests, and move from a lower satisfaction state to a higher satisfaction state. In the case of a negative manifested behaviour (e.g. rent seeking), a society faces the necessary (but not sufficient) condition of modifying individuals' social, legal and political environment, in an attempt to control any excessive form of institutional power. This scenario directly refers to the Rule of Law in a democratic system. This represents the best way to limit or control any possible manifestation of negative institutional manipulation and takeover. This is because mainline economic scholars have historically understood manifested 
individuals' behaviour as the reason why entrepreneurs can also be considered institutional planners.

However, it is important to see that institutional power has not only been allocated to the State as a central agent directing institutional planning, as it has been claimed and defended by legal positivism. In the European Civil Law tradition this perspective was already recognized and explored from a moral and juridical point of view. This discussion has led this legal tradition to examine the evolutionary and complex nature of formal and (in particular) informal institutions and their relation with the so-called legal concept of desuetude or desuetudo (in latin). As Ghersi (2007) has extensively defended, desuetude refers directly to informal institutions or the so-called custom contra legem. Under this theoretical figure and based on qualitative research, this legal scholar claims that in a social scenario categorised as an unstructured society, any kind of legislation and regulation will be unenforceable by the social fabric. Extending this argument to move away from the conventions of positive legal theory, we reject the idea that the courts represent the only agent capable of judging which transgressions are no longer valid or enforceable. In addition, the extension of the desuetude argument leads us to the lack of positive institutional interaction or institutional coordination as a social issue that has to be more extensively examined from the lack of legitimacy perspective. This is important because we face an example where unproductive entrepreneurs can observe a rent seeking opportunity and support their destructive behaviour because formal institutions lack legitimacy. Therefore this is an important variable that cannot be easily excluded from a further and consistent institutional assessment.

However, this theoretical exploration has not yet been presented in modern mainstream economic terms. Since institutions are also economic goods it can be stated that institutional manipulation or capture is also limited by time and practical knowledge (Huerta de Soto, 2011). This is important to understand because a society desiring to change its institutional production margins has to face an opportunity cost dilemma. It is not possible for a society to produce more units of $X$ institutions without affecting the number of $\mathrm{Y}$ institutions. This is a preliminary conclusion 
that will be shown by PPF analysis applied to institutions. The most interesting aspect of institutional transposition is when it is shown by the PPF' slope, since it shows the number of units of $\mathrm{Y}$ institutions which must be retired in order to produce or discover additional units of $X$ institutions. That is, it shows the «institutional interaction» or «opportunity cost of an institution» in terms of «another institution». If it is established that the slope is negative, it could mean, for example, that there is an inverse relationship between the volume of production and discovery of each of the Institutions. Equally, if the slope is positive, it could mean that when more $X$ institutions are produced, the greater the amount that could be generated for $\mathrm{Y}$ institutions, i.e. institutional wealth in quantitative terms would be unlimited. However, this assumption would be very difficult to verify in the real world.

Based on the previous findings, the opportunity cost of institutions can be defined as the exchange value of the second best institutional alternative. Effectively, the prevalence of an institutional framework or type may represent the abrogation of the second best choice because efficient and effective institutions are scarce. Determining the best allocation of social resources corresponds to a complex social process. In this scenario, institutions are clearly created in a competitive way because useful institutions are the result of human cooperation to reach individual targets first and then collective stability and order.

Noticeably, the PPF graph is used to understand institutional coordination and also shows two principal characteristics. The first is the negative slope: If an inverse relation exists between the level of institutional production/discovery of formal and informal institutions, an increase producing one of them will reduce the quantity produced or discovered of the other. The second is concavity: the slope probably will increase according to the growth of the amount of formal institutions and via the reduction of the number of informal institutions. 


\section{VI ELASTICITY'S DETERMINANTS
AND INSTITUTIONAL COORDINATION}

The first determinant of institutional elasticity corresponds to the ease with which a «formal institution» can be replaced by an «informal institution» and vice versa. Then the substitution of an institution depends first on its formal or informal «nature» and then from its ability to meet social objectives in terms of individual and collective choice. In this regard, an informal institution in a framework ruled by customs and interpersonal trust would be an example of a good with inelastic demand. Although an informal institution certainly has a potential substitute, such as alternative formal mechanisms supported by the formal institutional framework, none of these would be a strong substitute or a close enough alternative. On the other hand, formal institutions with an inefficient design will represent goods with elastic demand. These would be successfully substituted with informal institutions.

Therefore, the degree to which formal and informal institutions can be substituted or replaced will also depend on the restrictions or breadth of their theoretical definitions. For example, even though an informal institution would not have a close substitute, different types of informal institutions could replace each other without difficulty. This is named «intra-institutional» network competition.

In addition, the informal institutional framework may differ between regions and even between communities. Thus, it is also important to understand the characteristics of the institutional elasticity, especially if these refer to agents working on the costefficient and cost-effective development of public policy. This also means exploring potential negative effects while contemplating a change through «mandatory rules», including emergency decrees and laws for pro-mercantilist groups (Ghersi, 2009), in the formal institutional framework. In other words, to increase the equilibrium price of the current formal institutional framework. It is worth noting that a change in the price paid for the consumption of an additional formal institution (introduced by a legislator, a 
court or administrative agency) often ignores that the prices of other types of institutions may remain constant. Although the formal institutional framework of a country, region or territory has its own characteristics, other institutional types could substitute it and, therefore, potential consumers of this institutional framework can be very sensitive to changes in its relative price.

The second determinant of the elasticity of an institutional framework corresponds to the proportion of income directed to the consumption of an institution. Ceteri paribus means that the higher the proportion of income spent on the acquisition or use of an institutional instrument, the higher the elasticity. Therefore, if an agent should only invest a small portion of their income buying an institution, and then the relative price of an institution changes, that change will have little effect on the preferences and budget of an institutional consumer. Moreover, this determinant is observed particularly in a scenario where negative and destructive entrepreneurship prevails. In this case, the agents performing this kind of entrepreneurship will try to create barriers for those who wish to access the formal institutional framework, affecting the «budget» of those who could be considered potential competitors.

Consequently, a rise in the price of an institution introduced by negative entrepreneurship behaviour will absorb much of the budget of an institutional consumer, regardless of its size. In addition, it will encourage the institutional consumer to make a reassessment of their spending and actions and, finally, the evaluation of the formal institution's new price will result in new incentives for shifting and substitution in consumption. In other words, an institutional consumer will be in a situation where there is a lack of institutional coordination, which involves the rejection of more expensive institutional framework, and in many cases the named repeal of the law (Ghersi, 2010).

In order to appreciate the importance of the proportion of income spent in an institution, it can be considered its own demand elasticity. Thus, doubling the price of formal institutions will have a double effect. First, it will drastically decrease formal institutional consumption and will then introduce incentives 
that foster informal and illegal or parallel economies. Moreover, doubling the price of informal institutions will affect their consumption. However, more important consequences will arise: the introduction of an incentive to abandon these informal institutions. Their consequent disappearance will be marked by the emergence of other informal institutions and, the formal institutional framework will «finally» succeed. However, there is an important difference. Informal institutions have not only a consumer cost but also a high production cost. This production cost is not assumed directly by government and it is distributed between all layers of society. This cost spread or negative distribution could potentially introduce multiple problems such as negative externalities, adverse selection, free riders, etc. It is true that individuals often report a marked reluctance to take on additional costs because they are permanently looking to improve potential benefits. Nevertheless, there is an equal or even higher rate of refusal to use more expensive institutional frameworks versus less expensive alternatives.

The third determinant of the elasticity of an institutional framework would correspond to the time spent since its relative price has changed. In general, the longer the period, the greater the institutional elasticity of demand will be. The reason for this is related to the possibility of substituting an institution with another institution. As more time is required, there are more possibilities for a community or the whole social fabric of developing substitutes for the institution (often formal) that represents a high cost of compliance. Therefore, as necessary time has passed a community will have cheaper alternative or substitute institutions.

\section{The elasticity of the institutional framework in the short and long term}

An analysis of institutional framework supply and demand from the perspective of classical microeconomics perspective requires differentiating between the short run and the long run. In other words, if we ask how much demand changes an institutional framework in response to a price change, we have to consider the 
time frame (also understood as an objective matter) that society allowed before measuring variations in the quantity demanded of a particular institutional type. This period is one in which shortterm institutional changes in consumption occur. However, this is more complicated when it comes to long term, where changes in consumption of institutions cannot be determined accurately. This means that the long-term, in the case of such goods, refers to time it takes for consumers and producers to fully adapt to institutional variation in the relative price of formal and informal institutional frameworks. Therefore, if applied to institutions, the demand curves in the short term would also be very different from long-term curves as often happens in the case of other kind of goods. However, it is understood that institutional demand is more elastic with respect to long-term price than the price set out in the short term. This follows a common sense principle, which states that consumers of institutional assets (like other tangible or intangible goods) require time to change their consumption habits. For example, while the price of informal institutions will increase, the quantity demanded of such institutions would fall only gradually as consumers slowly begin to introduce alternative informal institutional arrangements or the use of formal institutional types that lack design defects and effectively reduce transactional costs.

In addition, it is essential to acknowledge that the discussion of changes in terms of elasticity applied to the study of the institutional framework is not a closed topic. That is, in some cases the opposite could happen: demand for certain informal institutions (within a natural replacement period of time following a change in the social atmosphere) could be more robust in the short term than the long term. Therefore, a small variation on the institutional framework - according to the current interests of consumerscould result in a large percentage change in the level of institutional consumption. However, it is clear that in most cases, «institutional dynamics» can be inserted as a priori that institutions are mostly long-term instruments and cannot be easily replaced, so the amount of institutions available in the short term can be treated, as one factor that remains constant. Therefore, institutional demand will be less elastic in the long run than in the short term. 


\section{Institutional Coordination and the problem of the legitimacy}

For a more traditional legal perspective, individual behaviour is not necessarily relevant to the extent that each isolated agent does not always have the capacity to negatively influence the interaction between formal and informal rules. Nonetheless, a more accurate assumption has to assume that the equilibrium or coordination between formal and informal institutions can be affected based on undesirable individual actions. It means that a society always has to face the risk of specific negative externalities introduced by agents such as politicians or some public servants and its subsequent inharmonious social cost effect.

In this regard, if we assume that if individual behaviour is not compliant with formal institutions and becomes a collectivized scenario, it will introduce a problem of widespread compliance costs where the marginal benefit of compliance with formal rules is lower that the marginal cost of compliance with formal rules. This problem can be formally represented as follows:

$$
B m g_{n}<\mathrm{C} g_{c}
$$

Where:

Bmgn = Benefit of compliance with formal rules .

$\mathrm{Cmgc}=$ Marginal cost of compliance with formal rules .

In addition, based upon an analysis of elasticity rules, it can be assumed that formal rules, in a scenario governed by institutional weakness, have to be described as highly elastic. While in a scenario of institutional strength there is a trend in formal rules of being less elastic. Moreover, in a scenario of institutional transition, there might be a higher chance of formal rules being elastic in nature. That is, the quantity demanded by individuals of formal rules is gradually reduced. It may be argued that individuals desire the introduction of more formal rules in a period of social crisis in order to solve their real world issues. However, our analysis will focus on actio and the Hayekian process of trial- 
error and not on human will or normative analysis as law scholars understand this. This means that our assumptions are strictly correlated with a positive economic analysis.

Another important point to consider is the nature of informal rules. Informal rules are basically complex and evolutionary idiosyncratic products with a particular character or taste: its potential legitimacy. Understanding a further relation between validity $^{10}(\mathrm{~V})$ and legitimacy $(\mathrm{L})$ requires departing from a first analytical stage. In this first stage, validity and legitimacy are equal in «terms of result», i.e. when valid rules are considered as legitimate.

$$
\mathrm{V}=\mathrm{L}
$$

The first stage reflects an equilibrium state. Nevertheless, this is a temporary, - sometimes - idealistic and perfect stage not consistent with a permanent social reality. The social process is always carried out in a state of permanent disequilibrium. However, this permanent state of disequilibrium does not represent a risk for societies where the internal dynamics of social change help societies to adjust to new circumstances, such as strong variations of the social fabric composition.

Furthermore, where there is a lack of institutional coordination, a so-called legitimacy gives an advantage to informal rules in the institutional framework. Even though informal rules are in open contradiction to the formally established formal institutional framework with support or enforcement forthcoming from the government. This particular context generates the conflict between validity and legitimacy where the institutional framework cannot meet a social equilibrium. Therefore, validity and legitimacy are not necessarily equivalent under an institutional exploration. ${ }^{11}$

${ }^{10}$ In this paper the concept of validity refers to the idea of «legal sufficiency». In addition, the concept of legitimacy refers to a «general social process where the popular acceptance of an institution and authority prevails».

11 These assumptions might require a further stress test. However, the purpose of this section was to introduce a broader analysis. 


\section{VII \\ THE BRAIN REWARD SYSTEM AND INSTITUTIONAL COORDINATION}

In order to strengthen the conceptual model as has been introduced in this paper, it is important to discuss contributions from the Neuroscience approach. That is to say, assuming a degree of interaction between the neuroscience approach and the theoretical proposal of institutional coordination requires some understanding of the main characteristics of the brain reward system.

The brain reward system comprises of dopaminergic pathways connecting the midbrain, the limbic system and the neocortex. It is a system based on dopamine (the neurotransmitter associated with pleasure and the development of addiction) that is activated when an individual perceives potential benefits, incentives or rewards. In addition, these rewards produce a pleasure reaction; this reaction can be activated by very diverse motivators, such as political power, money, health, etc.

Also, the neuroscience approach assumes that the greater activation of these structures, the higher the probability of making a decision in order to get a reward. Therefore, moving back to the example of individuals exercising their entrepreneurship function in a productive or destructive manner, individuals' decisions are also guided by this reward system or for-profit. This means that individuals are open to contribute or affect institutional coordination according to their expected benefits or guided by the desire to move from one stage of less satisfaction to one of greater satisfaction.

Additionally, it is important to acknowledge that each brain structure is activated by different states. On the one hand, the nucleus accumbens are activated when the pecuniary benefits or gains are greater, while the prefrontal cortex, involved in the calculation and in many cognitive functions, is activated when individuals perceive more chances to succeed in their projects. Moreover, the so-called system of loss aversion (or risk aversion) must also be taken into account for its significant implications when studying how individual actions influence institutional coordination. Although, the system of risk aversion is less well known than the 
brain reward system, it has been discovered that the brain structures involved in this system are the amygdala, the insula, the locus coeruleus and the hypothalamus. However, further studies are necessary in order to observe, describe and explore the relation among these structures and their potential ability to influence human behaviour or stimulate for or against the institutional framework.

In addition, the human brain shows a clear tendency for prediction and generation of patterns or simple rules related to dopamine and its reward system. Acknowledging this fact is important because it allows social scientists to understand that as a result of certain actions (for which an individual obtained a pecuniary benefit), the individuals' dopaminergic reward system is activated and it will enhance and reinforce learning patterns that have led to success. These learning patterns understood as an aggregate of behaviour guidelines are precisely equivalent to what Neo Institutional scholars call interpersonal constraints, institutions or rules. However, the aim of the study of the dopaminergic system should not simply be to encourage the establishment of an institutional framework. In fact, this statement mainly seeks to explain that within the institutional constraints scenario, a variable degree of institutional coordination can be perceived. Therefore, institutional coordination can differ among dissimilar social scenarios. Moreover, it can be assumed that incentives also occur for the establishment of a hierarchical order of interpersonal constraints and it is determined by the degree of individuals' compliance facing those institutional constraints.

Finally, another crucial element for the study of brain systems and institutional coordination is the relationship between evolution and institutional change and mirror neurons. The performance of mirror neurons is relevant, as they are primarily responsible for explaining why an individual reproduces other individual behaviour. Furthermore, the mirror neurons play an important role in cognitive abilities related to learning and social life and are related to empathy, imitation and social behaviours that direct informal (first) and formal institutions (after as a result of the coordination process institutional). 


\section{VIII \\ CONCLUSIONS}

1. This paper has shown that institutions are not merely a set or network of formal and informal rules. Institutions represent a complex and evolving social process. This is important when considering concepts like dynamic efficiency. In addition, based on the strong coordination between formal and informal rules, dynamic efficiency shows «adaptability» and the capacity of this coordinated institutional framework and network to generate:

a. Advanced changes to the social fabric;

b. Incentives to ease the process of adaptation of entrepreneurs.

Consequently, the «efforts» of economic and social agents and the strategic development of markets are part of this «dimension».

DiAgRAM 5

CRITERIA FOR INSTITUTIONAL COORDINATION

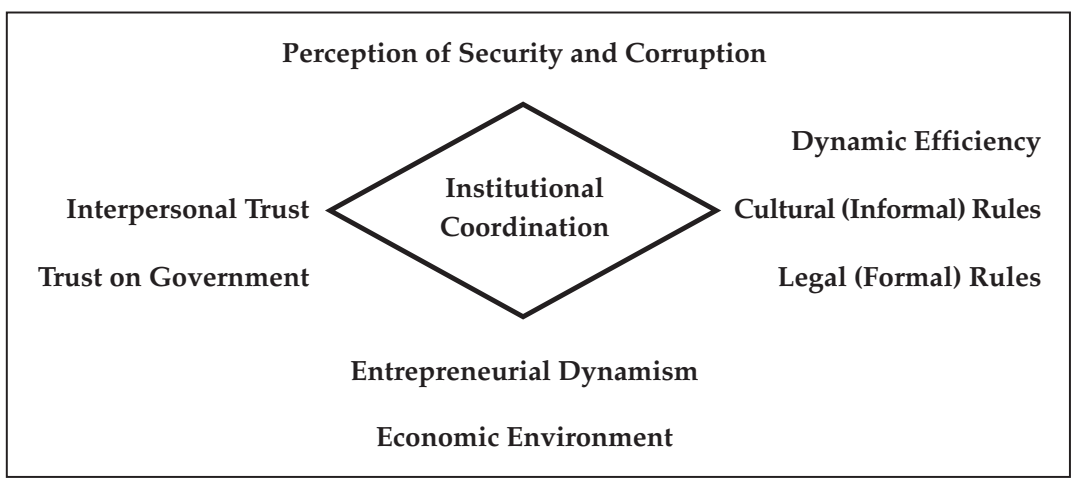

2. When a society does not have a positive interdependence between formal and informal institutions, social stagnation and institutional weakening prevail. In this social context, individuals cannot adapt to social change and exhibit negative social 
behaviours. This paper has proposed that the level of institutional weakening could be used as a social indicator to analyse and classify a society's social performance.

3. Without dynamic efficiency, limited political governance and the contribution of functional entrepreneurship, institutional coordination cannot be achieved. Then, as an undesirable consequence, destructive entrepreneurship can introduce «new rules» through mercantilist behaviour that becomes an institutionalized activity. Thus, this mercantilist behaviour will affect negatively the effectiveness and strength of the institutional coordination and its framework engaging indirect changes in it (guiding the social process to the transitional or even the unstructured society scenario). Furthermore, strong institutional coordination contributes to stable social cohesion (a main characteristic of structured societies). Consequently, a society lead by a tough social cohesion can display an environment of lower transaction costs and supply models of behaviour contributing to the rational formation of expectations.

4. Compromise solutions or trade-offs are a response to a scenario where formal institutions, by themselves, cannot efficiently reduce transaction costs. This is important because it determines that the process of interaction among institutional networks occurs within a wider orbit that implicates the organization of a social, political and economic system through «normative instruments» characterised by a broad illustrative character.

5. The first determinant of institutional elasticity corresponds to the ease with which a «formal institution» can be replaced by an «informal institution» and vice versa. Then the substitution of an institution depends first on its formal or informal «nature» and then from the ability to meet social objectives in terms of individual and collective choice. The second determinant of the elasticity of an institutional framework would correspond to the proportion of income directed to the consumption of an institution. Ceteri paribus posits that the higher the proportion of income spent on the acquisition or use of an institutional instrument, the higher the elasticity will be. Therefore, if an agent should only invest a small portion of income buying an institution, and then if there is 
a change in the relative price of an institution, that change will have little effect on the preferences and budget of an institutional consumer. The third determinant of the elasticity of an institutional framework corresponds to the time spent since its relative price has changed. In general, the longer the period the greater the institutional elasticity of demand will be. The reason for this is related to the possibility of substituting an institution by another institution. As more time is required, there are more possibilities for a community, or the whole social fabric, of developing substitutes for the institution (often formal) that represents a high cost of compliance. Therefore, when necessary time has passed a community will have alternative or institutional substitutes less costly.

6. For a society, it is not possible to produce more units of $X$ institutions without affecting the number of $Y$ institutions. It shows the institutional interaction or opportunity cost of an institution in terms of another institution. Based on this argument, the opportunity cost of institutions can be defined as the exchange value of the second best institutional alternative. Effectively, the prevalence of an institutional framework or type may represent the abrogation of the second best choice because efficient and effective institutions are scarce. Determining the best allocation of social resources is a complex social process where institutions are clearly created in a competitive way because useful institutions are the result of human cooperation to reach firstly individual targets and then collective stability and order.

7. In addition, the human brain shows a clear tendency for prediction and generation of patterns or simple rules related to dopamine and its reward system. Acknowledging this fact is important because it allows social scientists to understand that as a result of certain actions (for which an individual obtained a pecuniary benefit), the individuals' dopaminergic reward system is activated and it will enhance and reinforce learning patterns that have led to success. These learning patterns understood as an aggregate of behaviour guidelines are precisely equivalent to what Neo Institutional scholars call interpersonal constraints, institutions or rules. 


\section{BIBLIOGRAPHICAL REFERENCES}

Alonso, J.A. (2012): «Crítica de Libro: Why Nations Fail. The origins of Power, Prosperity, and Poverty» (by Acemoglu, D. and Robinson, J.A.), Principios. Estudios de Economía Política, n.. 21, Madrid: Fundación Sistema.

Alonso, J.A. and Garcimartin, C. (2008): Collective Action and Development. The Role of Institutions, Madrid: Editorial Complutense.

ArgoÑA, A. (1991): «Values, Institutions and ethics», Working Paper, n. ${ }^{\circ}$ 215, IESE Business School - University of Navarra Press.

Acemoglu, D. and Johnson, S. (2005): «Unbundling Institutions», Journal of Political Economy, vol. 113, n. 5, pp. 949995.

Ali, A. (2003): «Institutional Differences as Sources of Growth Differences», Atlantic Economic Journal, vol. 31, n.. 4, pp. 348362.

AOKI, M. (2001): Toward a Comparative Institutional Analysis, Cambridge - Mass: MIT Press.

- (2007): «Endogenizing Institutions and Institutional Changes», Journal of Institutional Economics, vol. 3, Issue 01, pp. $1-31$.

Axala, G. \& FABRo, J. (2008): «¿El Impacto de la calidad institucional sobre el crecimiento económico depende del nivel inicial de renta?», Economic Affairs, 28(3), 45-49.

BARRY, N. (1997): «The tradition of Spontaneous Order», LaissezFaire, n. ${ }^{\circ}$ 6, pp. 1-43, UFM Press.

Bassanini, A., Scarpetta, S. and Hemmings, P. (2001): Economic growth: the role of policies and institutions. OECD Press.

BAUMOL, W. (1968): «Entrepreneurship in economic theory». American Economic Review; 58(2), 64-7.

BAUMOL, W.J. (1990): «Entrepreneurship: Productive, Unproductive, and Destructive», The Journal of Political Economy, vol. 98, n.․ 5, pp. 893-921.

BECKER, G. (1983): «Una teoría de la Competencia entre grupos de presión por influencia política. Cuadernos Trimestrales de Economía», 98, 371-373. 
Benegas-Lynch, A. (2005): «El Conocimiento y la Ciencia: Algunas Consideraciones Hayekianas». Revista de Economía y Derecho, 2(5), 13-26.

Blundell, J. and Robinson, C. (2000): «La Regulación sin el Estado». Revista Libertas, 32, 4-22.

BOETTKe, P.J. and CoYne, C.J. (2003): «Entrepreneurshio and Development: Cause or consequence?», in Roger Koppl, Jack Birner, and Peter Kurrild-Klitgaard (ed.) Austrian Economics and Entrepreneurial Studies (Advances in Austrian Economics, Volume 6), Emerald Group Publishing Limited, pp. 67-87.

Calabresi, G. and Melamed, A.D. (1972): «Property Rules, Liability Rules and Inalienability: One View of the Cathedral», Harvard Law Review, vol. 85, p. 108.

CHANG, H. (2011): «Institutions and economic development: theory, policy and history», Journal of Institutional Economics, vol. 7, n. ${ }^{\circ}$ 4, pp. 473-498, Cambridge: Cambridge University Press.

CAVAdias, E. (2001): «El nuevo Institucionalismo en America Latina». Ciencias de Gobierno, 10, 11-25.

COASE, R.H. (1937): «The Nature of the Firm». Economica, 4 (16), 386-405.

- (1960): «The Problem of Social Cost». Journal of Law and Economics, 1(3), 1-44.

- (1994): La Empresa, el Mercado y la Ley. Madrid: Alianza Economía.

Cobin, J.M. (2009): Políticas Públicas: Tópicos Modernos de la Economía de Mercado para el Bienestar Social, Santiago de Chile: Fondo Editorial Universidad Andrés Bello.

Foss, N.J. and KLEIN, P.G. (2010): «Alertness, Action, and the Antecedents of Entrepreneurship», The Journal of Private Enterprise, vol. 2, pp. 145-164.

Furubotb, E.G. and Richter, R. (1998): Institutions and Economic Theory. The Contribution of the New Institutional Economics. Michigan: The University of Michigan Press.

Gagliardi, F. (2008): «Institutions and Economic Change: A Critical Survey of the New Institutional Approaches and Empirical Evidence», Journal of Socio-Economics, vol. 37, n.․ 1, pp. 416-443. 
Garcia-Guadilla, M.P. and Roa Carrero, E. (1997): «Civil Society, Classic Liberal Democracy and Market Economics: The Liberal Organizations in Venezuela», Estudios Científicos, Salamanca: Ediciones USAL.

GHERsI, S.E. (1988): «El Costo de la Legalidad». Centro de Estudios Públicos, 30, 83-110.

- (1991). «Economía de la Corrupción». Centro de Estudios Públicos, 73, 3-20

- (2005). «La Economía Informal en America Latina». Cato Journal, vol. 7(1), 1-14.

- (2007): «The competitive character of the Sources of Law», Revista de Instituciones, Ideas y Mercados, n.․․ 47, pp. 89-109.

- (2009): «Las consecuencias jurídicas del mercantilismo», EL CATO, Washington: Cato Institute.

GERBER, E.R. (1999): The Populist Paradox: Interest Group Influence and the Promise of Direct Legislation. Princeton: Princeton University Press.

GreIF, A. (1998): «Historical and Comparative Institutional Analysis», The American Economic Review, 88(2), 80-84.

Hart, H.L.A. (1980): El Concepto de Derecho. México: Editorial Nacional.

HAYEK, F.A. (1978): Law, Legislation and Liberty, University of Chicago Press.

Hellman, J. \& KaufmanN, D. (2001): «La captura del Estado en las economías en transición». Finanzas y Desarrollo, 38(3), 31-35.

Heyne, P.T, Prychitko, D.L. and BoettKe, P.J. (2009): The Economic Way of Thinking. Prentice Hall.

Hirshman, A.O. (1986): Interés Privado y Acción Pública. F.C.E. México.

Hodgson, G.M. (2006): What are institutions?, Journal of Economic Issues, vol. 40, n.. 1 .

- (1993): Economía y evolución: Revitalizando la Economía. Madrid: Colegio de Economistas de Madrid, Celeste Ediciones.

- (1998): «The Approach of Institutional Economics». Journal of Economic Literature, 36, 166-192.

- (2001): «How Economics Forgot History: The Problem of Historical Specificity in Social Science». Londres: Routledge. 
Huerta De Soto, J. (2009): The Theory of Dynamic Efficiency, Routledge.

- (2010): Socialism, Economic Calculation and Entrepreneurship, Edward Elgar.

KASPER, W. (2003): Building Prosperity: Australia's future as a global player. Sydney: The Centre for Independet Studies.

Kelsen, H. (2001): Introducción a la Teoría Pura del Derecho. Lima: Asociación Peruana de Derecho Constitucional.

KIRZNER, I.M. (1976): «Equilibrium versus Market Process», The Foundations of Modern Austrian Economics, Kansas City: Sheed and Ward Inc.

- (1978a). Competition and Entrepreneurship, University of Chicago Press.

- (1978b). Economics and Error, Kansas City: Sheed Andrews and McMeel.

Klein, P.G., Mahoney, J.T., Mcgahan, A. and Pitelis, C. (2010): «Toward a theory of public entrepreneurship», European Management Review, n.. 07, pp. 1-15. Milano: European Academy of Management.

MendeZ, R.C.B. (2011): «Institutional Innovation, Deregulation and Competition in a Structured Society». HDR Expo 2011, Sydney: Macquarie University Faculty of Business and Economics Press.

Menger, C. (1976 [1871]): Principles of Economics. Institute for Humane Studies.

NorTH, D. (1981): Growth and Structural Change, New York: W.W. Norton.

- (1990): Institutions, Institutional Change and Economic Performance, Cambridge: Cambridge University Press.

- (1991): «Institutions», Journal of Economic Perspectives, vol. 5, n.․ 1, pp. 97-112.

- (1994): «Economic Performance Through Time», American Economic Review, vol. 84, n. 3, pp. 359-368.

- (2005): Understanding the Process of Economic Change, New York: Princeton University Press.

Ostrom, E. (1990): Governing the Commons: The Evolution of Institutions for Collective Action, Cambridge: Cambridge University Press. 
Perez, E. (2001): Transitions (Theories of): changes in the Eastern countries, Madrid: Editora Critica de Ciencias Sociales.

Roux, D. (2006): The Prizes Nobel of Economics, Madrid: AKAL Economia Actual.

SAn EMeterio, N. (2006): New Institutional Economics, Madrid: Sintesis Press.

Schotter, A., (1981): The Economic Theory of Social Institutions, Cambridge: Cambridge University Press.

SobeL, R.S. (2008): «Testing Baumol: Institutional quality and the productivity of entrepreneurship», Journal of Business Venturing 23, pp. 641-655, Philadelphia: Elsevier Press.

Stigler, G. (1982): The Economist as Preacher, and Other Essays, Chicago: University of Chicago Press.

- (1992): «Law or Economics?», Journal of Law and Economics, 35, pp. 455-68.

Weber, M. (1930). The Protestant Ethic and the Spirit of Capitalism, London: Allen \& Unwin.

- (1964): Economy and Society, vol. I, p. 632, Mexico: Fondo de Cultura Económica

Williamson, O. (1985): The Economic Institutions of Capitalism: Firms, Markets, Relational Contracting, New York: Free Press. 